


\title{
DEGRADASI METHYLENE BLUE MENGGUNAKAN KATALIS ZnO-PEG DENGAN METODE FOTOSONOLISIS
}

\author{
Hary Sanjaya $^{\left.1^{*}\right)}$, Pinta Rida ${ }^{1)}$, Sherly Kasuma Warda Nigsih ${ }^{1)}$ \\ ${ }^{1)}$ JurusanKimia, FakultasMatematika Dan Ilmu Pengetahuan Alam, Universitas Negeri \\ Padang Jln. Prof.Dr.Hamka Air Tawar Padang, Indonesia Telp. 07517057420 \\ hary_sanjaya@yahoo.com, sherly14@fmipa.unp.ac.id,pintarida@yahoo.com
}

\begin{abstract}
Study about degradation of methylene blue using photosonolysis method has been done. This research aims to investigate effect of variation radiation times, $\mathrm{pH}$, and concentrations doping PEG (polyethylene glycol). The absorbance of samples was measured by a UV-Vis spectrophotometer. The result showed maximum time of irradiation to degradate methylene blue at 120 minutes, with percentage degradation is $94.55 \%$. The effect of $\mathrm{pH}$ showed maximum $\mathrm{pH}$ at 7 with percentage degradation is $96,83 \%$. Meanwhile, the effect of variation concentration doping PEG showed maximum result at $\mathrm{ZnO}-\mathrm{PEG} 15 \%$, with percentage degradation is $87,12 \%$. Sample was characterization by XRD, FTIR and UV-DRS. The XRD pattern showed wurtzite (hexagonal) structure and has crystal size of $47-88 \mathrm{~nm}$. FTIR spectrum showed that $425,33 \mathrm{~cm}^{-1}$ vibration strain for $\mathrm{Zn}-\mathrm{O}$. Analysis UV-DRS obtained band gap value is $3.19 \mathrm{eV}$.
\end{abstract}

Keywords: Degradation, methylene blue, ZnO-PEG, photosonolysis, wurtzite, band gap

PENDAHULUAN

Seiring dengan berkembang pesatnya dunia perindustrian pewarna sintetis akhirnya diciptakan untuk memenuhi keperluan industri yang digunakan membuat produk menjadi lebih cerah, lebih berwarna, dengan penggunaan yang cepat dan mudah. Akan tetapi bahan kimia yang digunakan dalam pembuatan pewarna sintetis tersebut umumnya bersifat racun, karsinogenik serta mudah terbakar. Jika pewarna sintetis ini terkandung di dalam limbah, akan sangat sulit untuk di hilangkan karena mengandung senyawa organik, tahan terhadap pengolahan secara aerob, stabil terhadap cahaya dan panas. Hal ini yang menyebabkan pewarna sintetis menjadi masalah ekologi [4], sehingga diperlukan penghilangan kontaminan organik dari limbah sebelum dibuang agar tidak merusak ekologi sekitarnya [7]

Salah satu pewarna sintetis yang banyak digunakan adalah methylene blue dengan rumus kimia $\mathrm{C}_{16} \mathrm{H}_{18} \mathrm{ClN}_{3} \mathrm{~S}$. Methylene Blue ini merupakan pewarna kationik dan senyawa hidrokarbon aromatik yang bersifat racun. Methylene Blue jika terkandung dalam air limbah dapat menimbulkan dampak bagi kesehatan mata, mual, muntah, serta diare $[8,12]$.

Sekarang telah banyak metode penanggulangan masalah limbah yang masih mengandung kontaminan organik, salah satunya metode oksidasi (AOPs) [5]. Advanced Oxidation Processes (AOPs) terdapat metode fotosonolisis 
yang mengkombinasikan fotolisis dan sonolisis [11]. Pada penelitian ini menggunakan fotokatalis semikonduktor zinc oxide $(\mathrm{ZnO})$ dengan band gap sebesar 3,37 eV dan energi ikat sebesar $60 \mathrm{MeV}$ [7].

Untuk meningkatkan aktifitas fotokatalitik dari $\mathrm{ZnO}$ dilakukan pendopingan dengan polyethylene glycol (PEG) [13]. Penambahan PEG diharapkan dapat meningkatkan efisiensi fotokatalis dan meningkatkan aktivitas fotokatalis dengan memperbesar luas permukaan spesifik [10]. Penelitian ini bertujuan untuk mendegradasi methylene blue menggunakan katalis ZnO-PEG dengan metode fotosonolisis.

\section{METODE PENELITIAN}

\subsection{Material}

Alat - alat yang digunakan pada penelitian ini adalah kotak fotokatalis yang terdiri dari lampu UV $(\lambda=254 \mathrm{~nm}$ dengan daya 60 watt) 3 buah dan Ultrasonik (45 KHz dengan daya 30 watt) merk Ultrasonic Cleaner 968, Oven merk $\mathrm{Xu} 225$ France Etuves, Neraca analitis merk Kern, Furnance merk Neycraft, Spektrofotometer UV-Vis merk (Agilent 8453), Fourier Transorm Infrared (FTIR) merk Perklin Elmer Frontier Optica, Xray Difraction (XRD) merkpANaltycal(9) $\mathrm{pH}$ meter merk Schott Instrument, Spektrofotometer UV-Diffuse Reflectance (UV-DRS) merk Analytic Jena, Peralataan gelas: labu ukur, gelas kimia, erlenmeyer, dan peralatan gelas standar lainnya. Bahan-bahan yang digunakan adalah zat warna methylene blue merk Merck KgaA, Zink Oxide (ZnO) merk BDH Chemicals, Serbuk PEG (BM 4000), Metanol p.a merk Merck KGaA, $\mathrm{HCl} 1 \mathrm{M}, \mathrm{NaOH} 1 \mathrm{M}$, Aquades.

\subsection{Eksperimental}

\subsubsection{Pembuatan model limbah methylene blue}

Model limbah methylene blue dibuat dengan melarutkan $0,5 \mathrm{~g}$ serbuk methylene blue dalam $1000 \mathrm{~mL}$ aquades, larutan ini disebut larutan induk. Sebanyak $20 \mathrm{~mL}$ larutan induk dipipet dan diencerkan dengan aquades hingga tanda batas $1 \mathrm{~L}$ sehingga diperoleh methylene blue dengan konsentrasi 10 ppm.

\subsubsection{Preparasi katalis ZnO-PEG}

Katalis $\mathrm{ZnO}$ sebanyak 0,475 gram dan serbuk PEG sebanyak 0,025 gram dilarutkan dalam metanol p.a sebanyak $100 \mathrm{~mL}$, lalu distirer selama 60 menit agar terbentuk sol yang homogen, dan distirer lagi selama 30 menit. Sol $\mathrm{ZnO}-$ PEG ini disonikasi selama 30 menit lalu dipanaskan dalam oven pada suhu 96-115 ${ }^{0} \mathrm{C}$ selama 60 menit. Selanjutnya dilakukan kalsinasi pada suhu $400{ }^{0} \mathrm{C}$ yang bertujuan untuk menguapkan semua pelarutnya hingga kering. Hasilnya didapatkan katalis ZnO-PEG 5\%. Prosedur yang sama dibuat untuk mendapatkan ZnO-PEG 10\%, 15\%, dan $20 \%$.

\subsubsection{Degradasi model limbah methylene blue secara fotosonolisis}

a. Penentuan pengaruh variasi lama penyinaran terhadap degradasi methylene blue

Larutan methylene blue dengan kosentrasi 10 ppm sebanyak $80 \mathrm{~mL}$ dimasukkan kedalam gelas piala $250 \mathrm{~mL}$, kemudian ditambahkan 0,1 gram $\mathrm{ZnO}$. Selanjutnya disinari dengan lampu UV $254 \mathrm{~nm}$ dan disonifikasi menggunakan ultrasonik pada frekuensi $45 \mathrm{KHz}$ dengan waktu berkala 15, 30, 45, 60, 75, 90, 105, dan 120 menit. Larutan hasil degradasi 
E-ISSN : 2549-7464, P-ISSN : 1411-3724

dianalisa dengan spektrofotometer UVVis.

b. Penentuan pengaruh variasi $\mathrm{pH}$ terhadap degradasi methylene blue

Larutan methylene blue $10 \mathrm{ppm}$ sebanyak $80 \mathrm{~mL}$ dimasukkan kedalam gelas piala $250 \mathrm{~mL}$, kemudian diatur $\mathrm{pH}-$ nya dengan menambahkan $\mathrm{HCl} 1 \mathrm{M}$ atau $\mathrm{NaOH} 1 \mathrm{M}$ hingga didapatkan pH 3. Selanjutnya ditambahkan 0,1 gram $\mathrm{ZnO}$ kedalam larutan methylene blue, lalu disinari dengan lampu UV $254 \mathrm{~nm}$ dan disonifikasi menggunakan ultrasonik dengan frekuensi $45 \mathrm{KHz}$ pada waktu lama penyinaran maksimum. Lakukan hal yang sama untuk pH 4, 5, 6, dan 7 . Larutan hasil degradasi dianalisa dengan spektrofotometer UV-Vis.

c. Penentuan pengaruh kosentrasi doping PEG terhadap degradasi methylene blue

Larutan methylene blue sebanyak $80 \mathrm{~mL}$ pada $\mathrm{pH}$ optimum ditambahkan dengan 0,1 gram ZnO-PEG 5\%. Larutan tersebut didegradasi dengan cara disinari menggunakan lampu UV $254 \mathrm{~nm}$ dan disonifikasi dengan alat ultrasonik dengan frekuensi $45 \mathrm{KHz}$ pada waktu maksimum. Hasil degradasi dianalisa dengan spektrofotometer UV-Vis. Lakukan hal yang sama untuk penambahan $\mathrm{ZnO}$-PEG 10\%, ZnO-PEG 15\%,dan ZnO-PEG $20 \%$.

\subsubsection{Karakterisasi Fotokatalis}

\section{a. Teknis analisis data}

Data yang diperoleh berupa absorbansi larutan methylene blue yang diukur dengan alat spektrofotometer UVVis. Analisis data dilakukan dengan membandingkan sisa larutan uji sebelum dan sesudah didegradasi serta perbandingan pada berbagai variasi lama penyianaran, variasi $\mathrm{pH}$, dan penambahan katalis ZnO-PEG. Persentase degradasi (\%D) dihitung dengan persamaan:

$$
D=\frac{\text { Ao }- \text { At }}{\text { Ao }} \times 100 \%
$$

dimana, $\mathrm{A}_{\mathrm{o}}\left(\mathrm{cm}^{-1}\right)$ adalah absorbansi mula-mula, $A_{t}\left(\mathrm{~cm}^{-1}\right)$ adalah absorbansi pada waktu $t$ [9]. Untuk melihat pengaruh penambahan PEG terhadap fotokatalis $\mathrm{ZnO}$ dilakukan karakterisasi dengan FTIR, XRD serta UV-DRS.

\section{b. Karakterisasi dengan XRD}

Struktur kristal diukur dengan instrumen XRD. Fotokatalis ZnO-PEG yang diukur dilihat dari doping PEG maksimum dari hasil fotodegradasi model limbah methylene blue secara fotosonolisis. Hasil karakterisasi dengan XRD untuk mendapatkan informasi morfologi dan bentuk kristal. Karakterisasi memperlihatkan pengaruh penambahan PEG terhadap ZnO. Dimana, pola difraktogram dapat digunakan untuk menentukan ukuran kristal (crystallite size) dengan menggunakan persamaan Scherrer:

$$
D=\frac{k \lambda}{\beta \cos \theta}
$$

dengan, D adalah ukuran kristal, $\mathrm{k}=0,94$ adalah konstanta Scherrer untuk kristal berbentuk sferis, $\lambda=0,154 \mathrm{~nm}$ adalah panjang gelombang sinar-X, $\beta$ adalah nilai FWHM masing-masing puncak karakteristik, $\theta$ adalah sudut difraksi.

\section{c. Karakterisasi dengan FTIR}

Fotokatalis ZnO-PEG yang diukur dilihat dari doping PEG maksimum hasil fotodegradasi model limbah methylene blue secara fotosonolisis. Hasil karakterisasi dengan FTIR untuk mendapatkan informasi gugus yang terdapat pada sampel $\mathrm{ZnO}-\mathrm{PEG}$.

\section{d. Karakterisasi dengan UV-DRS (UV-Diffuse Reflectance) \\ Katalis ZnO-PEG maksimum} dikarakterisasi dengan UV-DRS (UVDiffuse Reflectance). Hasil karakterisasi UV-DRS untuk mendapatkan informasi 
berupa lebar celah pita (band gap). Energi celah pita diperoleh dengan mengubah besaran \%R ke dalam faktor Kubelka-Munk (F(R)), sesuai dengan rumus sebagai berikut:

$$
F(R)=\frac{K}{S}=\frac{(1-R)^{2}}{2 R}
$$

dimana, $\mathrm{F}(\mathrm{R})$ adalah faktor KubelkaMunk, K adalah koefisien absorbansi, S merupakan koefisien scattering, dan $\mathrm{R}$ merupakan nilai reflektansi. Energi celah pita diperoleh dari grafik hubungan antara $h v(\mathrm{eV})$ vs $\left(\mathrm{F}\left(\mathrm{R}^{\prime} \infty\right) h v\right) 1 / 2$. Nilai $h v(\mathrm{eV})$ ditentukan dengan persamaan berikut:

$$
E g=h v=\frac{h c}{\lambda}
$$

dimana, Eg adalah energi celah pita (eV), $\mathrm{h}$ adalah tetapan Planck $(6,624$ x 10-34 Js), c adalah kecepatan cahaya di udara $(2,998 \times 108 \mathrm{~m} / \mathrm{s})$, dan $\lambda$ adalah panjang gelombang $(\mathrm{nm})$. Energi celah pita semikonduktor adalah besarnya $h v$ pada saat $\left(F\left(R^{\prime}\right) h v\right) 1 / 2=0$, yang diperoleh dari persamaan regresi linier kurva tersebut [1].

\section{HASIL DAN PEMBAHASAN}

\section{A. Degradasi Methylene Blue dengan Metode Fotosonolisis}

1. Penentuan Pengaruh Variasi Lama Penyinaran

Proses degradasi methylene blue dilakukan dengan kosentrasi awal 10 ppm. Penentuan lama penyinaran terhadap proses fotosonolisis methylene blue dilakukan dengan cara memvariasikan lama waktu penyinaran dari 15 menit sampai 120 menit dengan waktu berkala 15 menit.

Absorbansi methylene blue setelah didegradasi dengan metode fotosonolisis dengan variasi lama penyinaran 15,30 , 45, 60, 75, 90, 105, dan 120 menit menunjukkan semakin lama waktu penyinaran, absorbansi yang dihasilkan semakin rendah. Hal ini menunjukkan persentase degradasi methylene blue semakin besar. Berdasarkan hasil perhitungan, didapatkan \%D larutan methylene blue yang paling tinggi yaitu $94,55 \%$ pada waktu 120 menit dan yang paling rendah pada waktu 15 menit dengan \%D adalah 73,23\%. Adapun kurva pengaruh lama penyinaran terhadap persentase degradasi methylene blue dapat dilihat pada Gambar 1.

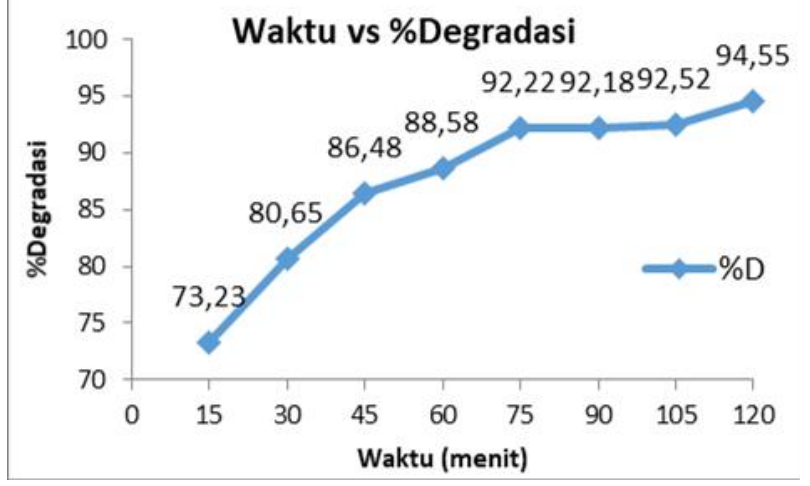

\section{Gambar 1. Kurva Pengaruh Lama Penyinaran terhadap Degradasi Larutan Methylene Blue Menggunakan Katalis $\mathrm{ZnO}$ dengan Metode Fotosonolisis.}

Gambar 1 memperlihatkan pengaruh lama penyinaran terhadap persentase methylene blue yang terdegradasi. Persentase methylene blue yang terdegradasi terlihat semakin meningkat seiring dengan bertambahnya lama waktu penyinaran, karena semakin banyak foton yang mengenai katalis $\mathrm{ZnO}$, sehingga jumlah radikal hidroksil $(\bullet \mathrm{OH})$ yang dihasilkan semakin bertambah. Radikal $\bullet \mathrm{OH}$ ini yang akan menyerang molekul methylene blue dan mendegradasinya menjadi senyawa yang lebih sederhana [3]. Berdasarkan data diatas, menunjukkan bahwa pengaruh lama penyinaran maksimum degradasi methylene blue adalah 120 menit. 


\section{Penentuan Pengaruh Variasi $\mathrm{pH}$}

Pada penelitian ini pengaruh $\mathrm{pH}$ dipelajari terhadap larutan methylene blue $10 \mathrm{ppm}$ dalam beberapa variasi $\mathrm{pH}$ yaitu $3,4,5,6$, dan 7 yang didegradasi secara fotosonolisis. Waktu yang digunakan untuk mendegradasi yakni selama 120 menit, yang merupakan waktu penyinaran maksimum yang diperoleh untuk mendegradasi methylene blue.

Persentase degradasi larutan methylene blue yang paling tinggi yaitu 96,83\% pada $\mathrm{pH} 7$ dan yang terendah $94,20 \%$ pada $\mathrm{pH} 3$. Adapun kurva pengaruh $\mathrm{pH}$ terhadap persentase degradasi methylene blue dapat dilihat pada Gambar 2.



Gambar 2. Kurva Pengaruh $\mathrm{pH}$ terhadap Degradasi Larutan Methylene Blue Menggunakan Katalis $\mathrm{ZnO}$ dengan Metode Fotosonolisis.

Gambar 2 memperlihatkan pengaruh $\mathrm{pH}$ terhadap persentase methylene blue yang terdegradasi. Persentase degradasi mengalami peningkatan seiring dengan peningkatan $\mathrm{pH}$ namun mengalami penurunan pada $\mathrm{pH}$ 5. Semakin tinggi nilai $\mathrm{pH}$ maka akan semakin banyak terbentuk ion $\mathrm{OH}^{-}$yang akan mengakibatkan peningkatan jumlah radikal hidroksil $(\bullet \mathrm{OH})$ yang terbentuk. Banyaknya radikal hidroksil yang terbentuk mengakibatkan semakin banyak methylene blue yang akan terdegradasi [3].

\section{Pengaruh konsentrasi doping PEG}

Absorbansi methylene blue blue setelah didegradasi dengan metode fotosonolisis dengan variasi kosentrasi PEG 5, 10, 15, dan 20\% menunjukkan bahwa penambahan PEG dengan kosentrasi $5 \%$ sampai $15 \%$ mengalami penurunan absorbansi dan kembali naik pada penambahan 20\%. Adapun kurva pengaruh jumlah kosentrasi doping PEG terhadap persentase degradasi dapat dilihat pada Gambar 3.

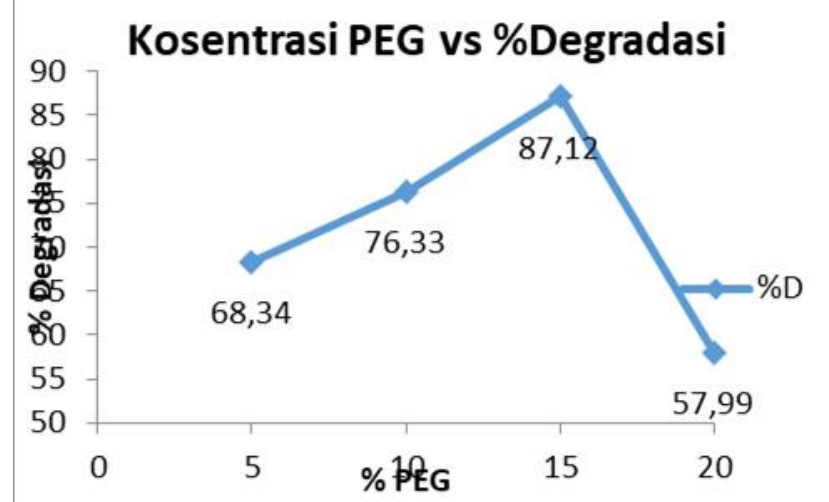

Gambar 3. Kurva Pengaruh Doping PEG Terhadap Degradasi Larutan Methylene Blue Menggunakan Katalis $\mathrm{ZnO}$ dengan Metode Fotosonolisis.

Gambar 3 menunjukkan peningkatan kenaikan persentase degradasi secara signifikan hingga penambahan PEG 15\%, hal ini menunjukkan kemampuan katalis $\mathrm{ZnO}$ yang berkombinasi dengan PEG dapat bekerja secara bersamaan dalam proses degradasi sampel. Pada penambahan doping PEG 20\%, terlihat penurunan persentase degradasi. Hal ini menunjukkan bahwa penambahan PEG yang berlebih akan menyebabkan bagian sisi aktif dari katalis yang berkontak dengan sampel tidak mendapatkan penetrasi foton yang optimal dan memungkinkan akan terjadi rekombinasi 
elektron dan hole sebelum sampai pada permukaan. Berdasarkan uraian diatas, dapat disimpulkan bahwa penambahan doping PEG $15 \%$ merupakan kosentrasi doping PEG maksimum yang diperoleh dalam mendegradasi sampel methylene blue dengan persentase degradasi sebesar $87,12 \%$.

\section{B. Karakterisasi}

1. Karakterisasi $\mathrm{ZnO}$ dan $\mathrm{ZnO}-\mathrm{PEG}$ dengan XRD

Karakterisasi menggunakan XRD dilakukan untuk mendapatkan informasi struktur dan ukuran kristal dari katalis $\mathrm{ZnO}$ dan $\mathrm{ZnO}-\mathrm{PEG}$.

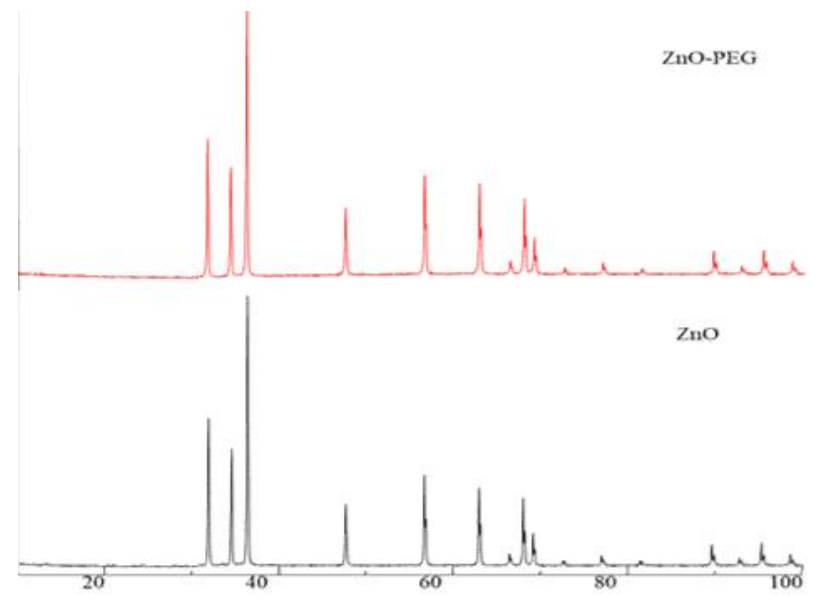

Gambar 4. Difraktogram (a) ZnO- PEG dan (b) $\mathrm{ZnO}$

Gambar 4 menunjukkan adanya puncak-puncak dengan intensitas tinggi dari sampel $\mathrm{ZnO}$ dan ZnO-PEG. Difraktogram $\mathrm{ZnO}$ dan $\mathrm{ZnO}-\mathrm{PEG}$ ini dicocokkan dengan data ICDD (International Center for Diffraction Data). Hasil yang diperoleh menunjukkan bahwa struktur kristal dari $\mathrm{ZnO}$ komersil adalah struktur hexagonal (wurzite).

Pola difraktogram yang diperoleh juga dapat digunakan untuk menentukan ukuran kristal (crystallite size) dari katalis $\mathrm{ZnO}$ dan $\mathrm{ZnO}-\mathrm{PEG}$ berdasarkan nilai
FWHM (Full Width at Half Maximum) pada berbagai puncak dengan menggunakan persamaan Scherrer.

$$
D=\frac{k \lambda}{\beta \cos \theta}
$$

Berdasarkan perhitungan yang telah dilakukan diperoleh ukuran kristal $\mathrm{ZnO}$ berkisar 48, 90 - $81.32 \mathrm{~nm}$ dan ZnO-PEG berkisar 47,00 nm - 88,80 nm. Ukuran kristal ini tergolong kedalam kristal yang berukuran nanometer, karena ukuran kristalnya berkisar antara 0-100 nm. Penambahan polimer berupa polyethilen glycol (PEG) pada katalis $\mathrm{ZnO}$ menambah besar ukuran partikel kristal yang dihasilkan. Hal ini menunjukkan bahwa katalis $\mathrm{ZnO}$ telah berhasil di doping dengan PEG

2. Karakterisasi $\mathrm{ZnO}$ dan $\mathrm{ZnO}-\mathrm{PEG}$ dengan FTIR

Analisa FTIR dilakukan pada sampel katalis $\mathrm{ZnO}$ dan $\mathrm{ZnO}-\mathrm{PEG} 15 \%$. Sampel yang digunakan yang merupakan sampel katalis $\mathrm{ZnO}$ komersil dan $\mathrm{ZnO}$ PEG yang dilihat dari doping PEG maksimum dari hasil fotodegradasi model limbah methylene blue secara fotosonolisis. Spektra FTIR dari katalis $\mathrm{ZnO}$ dan $\mathrm{ZnO}-\mathrm{PEG}$ dapat dilihat pada Gambar 5.

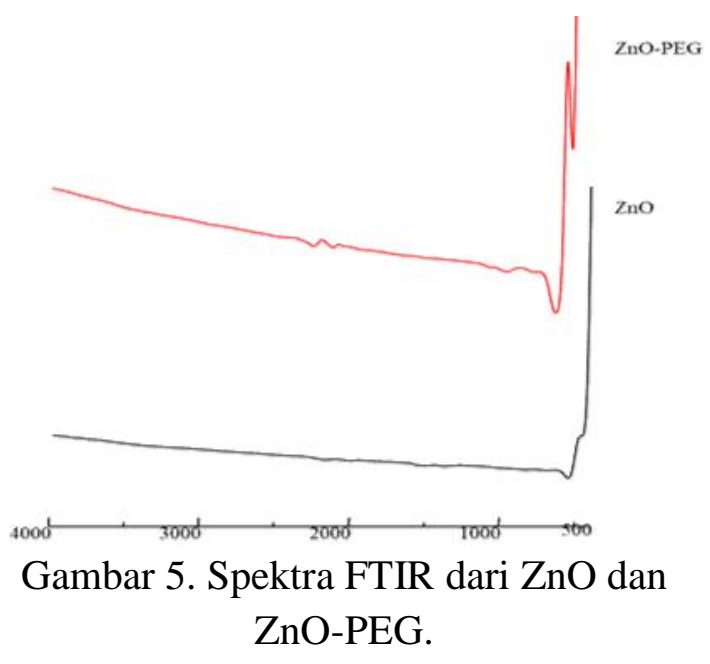


Puncak serapan tajam pada bilangan gelombang 425,33 $\mathrm{cm}^{-1}$ menunjukkan daerah regangan $\mathrm{Zn}-\mathrm{O}$. Penelitian yang dilakukan oleh [15], [14], dan [2] juga menyebutkan daerah renggangan $\mathrm{Zn}-\mathrm{O}$ berada pada daerah bilangan gelombang 400-500 $\mathrm{cm}^{-1}$. Puncak serapan pada bilangan gelombang 541,84 $\mathrm{cm}^{-1}$ menunjukkan vibrasi tekuk O-H dari gugus hidroksil dan bilangan gelombang $877,97 \mathrm{~cm}^{-1}$ menunjukkan terbentuknya koordinasi tetrahedral dari Zn [6].

3. Analisis Band Gap $\mathrm{ZnO}$ dan $\mathrm{ZnO}-$ PEG dengan UV-DRS

Analisis dengan menggunakan UVDRS hanya dilakukan pada sampel ZnOPEG 15\% yang merupakan sampel katalis ZnO-PEG maksimum yang dilihat dari hasil fotodegradasi model limbah methylene blue secara fotosonolisis. Grafik band gap dari ZnO dan ZnO-PEG terlihat pada Gambar 6.

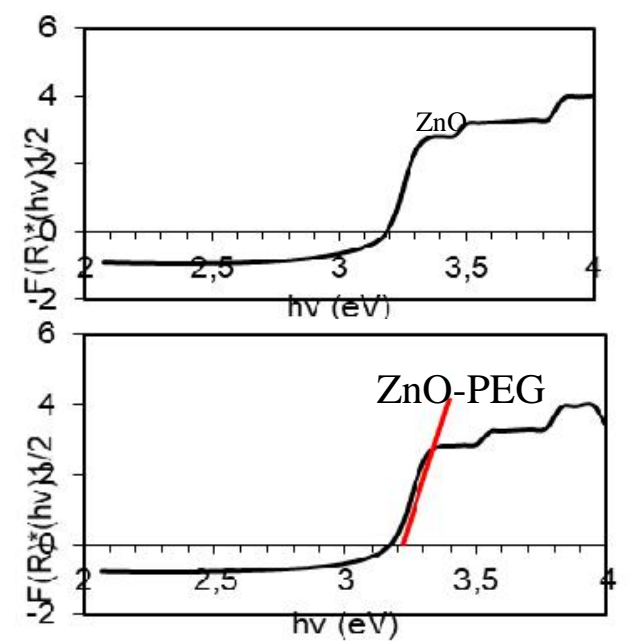

Gambar 6. Grafik nilai band gap $\mathrm{ZnO}$ dn ZnO-PEG dengan menggunakan UV-DRS.
Nilai band gap dari semikonduktor dapat dihitung dengan menggunakan teori Kubelka-Munk. Nilai band gap dari $\mathrm{ZnO}$ dan ZnO-PEG dihitung dari spektra reflektan. Berdasarkan Gambar 11, terlihat nilai band gap yang diperoleh untuk $\mathrm{ZnO} \sim 3,2 \mathrm{eV}$ dan $\mathrm{ZnO}-\mathrm{PEG} \sim 3,18$ $\mathrm{eV}$. Hal ini menunjukkan bahwa dengan pendopingan PEG pada katalis $\mathrm{ZnO}$ menurunkan nilai band gap. Akan tetapi, kecilnya nilai band gap yang diperoleh pada ZnO-PEG tidak memiliki korelasi dengan aktifitas fotokatalitik yang dihasilkan.

\section{KESIMPULAN DAN SARAN}

\section{A. Kesimpulan}

Berdasarkan penelitian yang telah dilakukan, dapat disimpulkan bahwa.

1. Lama penyinaran maksimum yang diperoleh untuk mendegradasi methylene blue 10 ppm menggunakan katalis $\mathrm{ZnO}$ secara fotosonolisis adalah 120 menit, dengan persentase degradasi sebesar $94,55 \%$.

2. Nilai pH maksimum yang diperoleh untuk mendegradasi methylene blue $10 \mathrm{ppm}$ menggunakan katalis $\mathrm{ZnO}$ secara fotosonolisis adalah $\mathrm{pH} \mathrm{7,}$ dengan persentase degradasi sebesar $96,83 \%$.

3. Kosentrasi doping PEG maksimum yang diperoleh untuk mendegradasi methylene blue $10 \mathrm{ppm}$ secara fotosonolisis adalah 15\%, dengan persentase degradasi sebesar $87,12 \%$.

\section{B. Saran}

Disarankan bagi peneliti selanjutnya:

1. Untuk mempelajari pengaruh doping lainnya dalam mendegradasi zat warna (dye). 
2. Untuk mempelajari proses degradasi zat warna lainnya dengan menggunakan metode fotosonolisis.

3. Untuk dapat mempelajari pengaruh jumlah katalis, kosentrasi larutan serta efektivitas proses degradasi zat warna.

\section{DAFTAR PUSTAKA}

Abdullah Mikrajuddin, Khairurrijal. 2008. Nanopartikel Ceria yang Didop Neodimium untuk Aplikasi Solid Oxide Fuel Cell (SOFC). Bandung: Institut Teknologi Bandung.

Ayu. D.W., Ni Putu Diantariani., dan Sri Rahayu Santi. 2015. Pembuatan Komposit ZnO-Arang Aktif Sebagai Fotokatalis Untuk Mendegradasi Zat Warna Metilen Biru. Jurnal Kimia. Jurusan Kimia. Fakultas Matematika dan Ilmu Pengetahuan Alam. Universitas Udatyana. Bali. Vol. 1. 109-116.

Diantariani, N.P. Widihati, dan Ratih Megasari. 2014. Fotodegradasi Metilen Biru dengan Sinar Ultraviolet dan Katalis ZnO. Jurnal Kimia. Jurusan Kimia FMIPA. Universitas Udayana. Bali. Hal 137-143

George, Kyzas., Jie F., Kostas A. 2013. The Change from Past to Future for Absorbent Material in Treatmentof Dyeing Wastewater. Journal MDPI. Vol 6.

Houas, A., Lachheb, H., Ksibi, M., dan Elaloui, E. 2001. Photocatalytic Degradation Pathway of Methylene Blue in Water. Journal Elsevier.
Applied Catalyst B: Environmental. Vol 31.

Javed, R., Muhammad Usman., Saira Tabassum dan Muhammad Zia. 2016. Effect of Capping Agents: Structural,Optical and Biological Properties of $\mathrm{ZnO}$ Particles.Applied Surface Science. Researchgate.

Mun, Kian Lee., Chin W.L., Koh, S.N danJoon, C. J. 2015. Recent Development of Zink Oxide Based Photocatalyst in Water Treatment Technology: A Review. Water Research. Journal Elsevier. Vol 88.

Palupi, Endang. 2006. Degradasi Methylene Blue Dengan Metode Fotokatalisis dan Fotoelektrokatalisis Menggunakan Film TiO2. Bogor: FMIPA ITB.

Parshetti, G. K., Parshetti, S. G., Telke, A. A., dan Kalyani, D. C., Doong, R. A. dan Govindwar, S. P. 2011. Biodegradation of Crystal Violet by Agrobacteriumradiobacter. Journal of Environmental Science. Vol. 23. No.8.

Pratama, Rezki. 2012. Penentuan Kondisi Optimum Proses Degradasi Zat Warna Methylene Blue pada Reaktor Fotokatalitik TiO2-PEG. Padang: FMIPA UNP.

Rashid, M dan Chikashi Sato. 2011. Photolysis, Sonolysis, and Photosonolysis of Tricloroethane (TCA), Tricloroethylene (TCE), and Thetracloroethylene (PCE) Without Catalyst. Journal Water Air Soil Pollutant. Vol 216. 429-440. 


\section{Eksakta Vol. 18 No. 2 Oktober | 2017}

E-ISSN : 2549-7464, P-ISSN : 1411-3724

Salehi, M., Hashemipour, H., Mirzaee, M., 2012. Eksperimental Study of Influencing Factors and Kinetics in CatalyticRemoval of Methylene Blue with $\mathrm{TiO} 2$ Nanopowder. American Journal of Environmental Engineering. Vol 2.

Sistesya, DilladanSusantoHeri. 2013. Sifat Optis LapisanZnO: Ag yang Dideposisikan Diatas Substrat Kaca Menggunakan Metode Chemical Solution Deposition (CSD) dan Aplikasinya pada Degradasi Zat
Warna Metylene Blue. Youngster Physics Journal. Vol 1.No. 4.

Suwanbon. S. 2008. Structural and optical properties of nanocrystalline $\mathrm{ZnO}$ powder from sol-gel method. ScienceAsia, Vol.34. No. 1, pp. 3134.

Thirugnanam, T. 2013. Effect of Polymers (PEG and PVP) on SolGel Synthesis of Microsize Zinc Oxide. Journal of Nanomaterial. Hindawi Publishing Corporation. Vol. 2013. 